\title{
DIVERSIFICATION OF BUSINESS AND TECHNICAL EFFICIENCY OF COMPANIES IN VIETNAM
}

\author{
Anh Phong Nguyen \\ University of Economics and Law, Ho Chi Minh City, Vietnam \\ Vu Anh Nguyen \\ University of Economics and Law, Ho Chi Minh City, Vietnam \\ Vietnam National University, Ho Chi Minh City, Vietnam \\ Thi Hong Minh Ho \\ University of Economics and Law, Ho Chi Minh City, Vietnam \\ Vietnam National University, Ho Chi Minh City, Vietnam \\ Thi Thanh Truc To \\ University of Economics and Law, Ho Chi Minh City, Vietnam \\ Vietnam National University, Ho Chi Minh City, Vietnam
}

\begin{abstract}
This study focuses on assessing the technical efficiency of enterprises across 63 provinces of Vietnam from 2015 to 2018 and the factors affecting their technical efficiency, in which, we focus on two factors: business diversification and an Information and Communication Technology (ICT) index. In this research, we use the data envelope analysis (DEA) method to group effective and ineffective enterprises, then use the GMM method to estimate the factors affecting the firm's performance. The research results show that the technical efficiency of enterprises in the provinces is quite small (about $10 \%$ ); most of the enterprises have not achieved technical efficiency due to the wasteful use of input factors. Research shows that business diversification and ICT both have a positive impact on efficiency. Therefore, to increase firm's efficiency, we recommend to consider increasing the level of diversification and increasing the ICT index from the perspective of businesses and local government.
\end{abstract}

Keywords: diversification, technical efficiency, Vietnamese companies

DOI: http://dx.doi.org/10.15549/jeecar.v8i4.772

\section{INTRODUCTION}

As we all know, the $4^{\text {th }}$ industrial revolution has ushered in changes in all areas of social life, from production, trade, investment, and consumption. Its strong development is based on digitalization and applications of artificial intelligence or 
machine learning, which have significantly improved economic and social efficiency through high accuracy, safety and low cost. The development of terms such as the digital economy, digital business and digital investment... are terms no longer strange to us. They come from digitalization in all fields, combining computer science and data science, especially the great innovation in Information and Communication Technology (ICT) (David Mhlanga, 2021). It was the advent of the personal computer, internet and digitalization that spurred the growth of other industries (Eden, 2018). ICT has led to changes in manufacturing processes, the way of doing business, investment and the way the private sector or public sector is managed. Therefore, it can be stated that the strong development of social networks and the digital economy have changed the methods and ways of production in a broad range of areas and industries and demonstrates the impact of ICT on economic activities. ICT is creeping into all business activities in all enterprises, from the practical activities of social life to the most complex ones. (David Mhlanga, 2021)

From a macro perspective, a number of recent studies have shown that ICT will bring positive value to economic growth (Khuong, 2019). From a micro perspective, current studies also argue in two ways. One way that ICT helps is to create competitive advantages and enhance the performance of enterprises (Apulu et al, 2011; Yunis et al, 2018; and Brynjolfsson and Hitt,1993). Other studies such as Roach (1991), Loveman (1998), Samwel Macharia Chege et al. (2020) suggest that investment in ICT does not increase productivity and efficiency in business, Research on other aspects, typically Brooke (1991), argue that the initial impact and goal of ICT is to increase product diversification. Omar A. León et al. (2016) show that advances in ICT have paved the way for a myriad of new opportunities for companies to broaden their horizons to explore new markets and diversify business activities. In Vietnam, there are also studies on the impact of ICT on business activities such as research by Bui Trinh (2020), Dang Thi Viet Duc (2019). However, these studies mainly assess the impact of ICT on Vietnam's economy and do not analyze the impact of ICT on business performance.
Our study addresses the gaps of previous studies in combining the two methods of data envelope analysis (DEA) and GMM in both classifying effective enterprises and assessing factors affecting firm performance. We are interested in the ICT factor because Vietnam has a development policy that is different from other countries which have had an ICT development policy for a long time.

Vietnam is in the process of digital transformation, however, and has many opportunities to attract investment capital in technology, in addition to policies on supporting and promoting technology applications in economics and management. Provinces in the country are also implementing governmentoriented digital transformation, but, under different resources, ICT development capabilities also are different. Therefore, this study is very urgent and meaningful to businesses in each of Vietnam's provinces and contributes to each local government in reforming its own policies, both responding to the trend toward digitalization and making contributions to help businesses enhance efficiency and productivity.

The remainder of the paper is organized into five sections. Section 2 is devoted to a brief review of the related literature. We set out a brief description of the data and econometric approach in Section 3. Section 4 presents the descriptive statistics and experimental results, while the conclusion is reported in Section 5.

\section{LITERATURE REVIEW}

Studies on the impact of ICT and diversification on the efficiency and technical efficiency of enterprises have two apparent trends. One set of studies that show that ICT has a positive impact on business performance. Typical of these are Roberto Alvarez et al. (2001), who analyze and evaluate the technical efficiency of small and medium enterprises (SMEs) by applying the DEA method, where the input variables used are labor and capital, and the output variable is total revenues. The results show that human factors positively affect efficiency, investment in increasing production, and product innovation. Research by Roghieh Gholami et al. (2004) used data from 22 manufacturing industries in Iran from 1993-1999 to evaluate the impact of ICT on productivity. The result shows that ICT 
contributes to the increase in productivity from inputs such as intangible and tangible assets. Having the same point of view, Phillip Koellinger (2006) argued that ICT innovation is positively related to revenue growth and productivity in firms. Samwel et al. (2019) pointed out that technology innovation has a positive effect on corporate operations, however the shortcoming of the study was its limitation in the scope of sampling and loss of generaliability. This suggests that the government should have relevant policies to promote the construction of infrastructure to better develop information technology.

In contrast, the study of Rafi Ashrafi et al. (2008) found that only a small number of SMEs showed benefits from the application ICT in their business activities. The research of Jose'Fernández-Menéndez et al. (2009) used DEA in calculating and estimating the technical efficiency of enterprises. The results show that ICT has a positive impact on technical efficiency. Yusof et al. (2006) also used DEA to analyze and evaluate the efficiency of companies in Malaysia in the period 2004-2008. The results showed that the inefficiency is mainly due to firms being inefficient by scale rather than by purely technical inefficiency. Dolores Añón Higón (2011) introduced the role of ICT on the performance of SMEs. This study used data collected annually from SMEs. In this study, the author used the input variable as ICT, and the output variable is process and product innovation. The results of the study showed that there are two effects of ICT on the company and the external environment. Ngo (2010) applied the DEA method to analyze the change in operational efficiency over the time period 19902010. The results found that performance decreases over time as the scale increases, when financial markets are more liberal and when global and regional economies face problems. You et al. (2020) used the method of analysis of financial ratios combined with DEA on data from 24 listed companies in Taiwan. The results showed that most of the companies achieved the efficiency level from 0.94 to 1.00 .

Up to the present time there have been many studies across the globe on the impact of business diversification on the financial efficiency of enterprises. These studies assess the diversification index by two methods: the method of measurement scale by survey, such as the studies of Enrico Santarelli and Hien Tran (2013) and Pandya and Rao (1998), which classified companies into three diverse groups; P.G Berger and E.Ofek (1995), who classified companies into two groups, single-segment firms and multi-segment firms; and studies which used methods of using diversification indicators such as the entropy index, such as Berger and Ofeck (1995), Stephen Tallman and Jiatao Li (1996), and Hao Shen, Dong Wang and Zhongfeng Su (2011). In Vietnam, the most recent research by Long Hau LE and Tan Nghiem LE (2020), studied the factors affecting the income diversification of households in the Mekong River delta. In general, approaches to and indicators on diversification are numerous, from product diversification, industries, revenues and geography to income diversification and investment.

In summary, the above studies mostly used two evaluation models, including the model to evaluate technical efficiency, then used the results to evaluate factors affecting technical efficiency by various methods such as logit and tobit. The findings show that there is inconsistency in the impact of ICT on efficiency. Most studies show that ICT has a positive effect on efficiency, but on the other hand some state that it has a negative impact. Besides, there is an indirect relationship between ICT and business diversification; diversification helps to enhance efficiency but sometimes also reduce efficiency. The studies mainly used data of enterprises in general, not disaggregated by region or province.

\section{METHODOLOGY}

\section{Data Setting}

Research data includes ranking reports on the ICT index of provinces, and indicators on production, business, finance of enterprises in 63 different provinces. Data are collected from 2015 to 2018. The details of the calculation and data sources are as follows:

First, in regards to data on production, business and finance indicators of enterprises in 63 provinces and cities, we used the source "The white book on Vietnamese businesses year 2019 and 2020", including basic information to assess 
the level of business development in the country and regions in the 2016-2018 period.

Second, in terms of the ICT index of provinces and cities, we collected this index from "The report on assessing, ranking the readiness for ICT development and application in Vietnam, Vietnam ICT index rankings" through the year from 2015 to 2018, conducted by the Ministry of Information and Communication and the Vietnam Informatics Association.

\section{Model Specifications:}

In this study, we used the input and output efficiency evaluation model according to the DEA method and used the model to evaluate the factors affecting the firm's performance by the GMM method. Details are presented as follows:

Model assessing technical efficiency of enterprises based on DEA method

We synthesized previous studies on parametric and non-parametric methods, input and output variables to apply to the study.

Table 1: Selection of input and output variables for measuring technical efficiency

\begin{tabular}{|c|c|c|c|c|}
\hline Author & Data & Method & $\begin{array}{l}\text { Output } \\
\text { variable }\end{array}$ & Input variable \\
\hline $\begin{array}{l}\text { Nguyen Viet } \\
\text { Hung, } 2008\end{array}$ & $\begin{array}{l}32 \text { commercial banks } \\
\text { in Vietnam, period } \\
2001-2005\end{array}$ & $\begin{array}{l}\text { DEA and Malmquist } \\
\text { index; model of } \\
\text { marginal } \\
\text { production function }\end{array}$ & $\begin{array}{l}\text { Employee cost; } \\
\text { Capital; Total } \\
\text { deposit }\end{array}$ & $\begin{array}{l}\text { Total loan; Interest } \\
\text { earned; Non-interest } \\
\text { expenses }\end{array}$ \\
\hline $\begin{array}{l}\text { Jose 'Ferna'ndez et } \\
\text { al., } 2009\end{array}$ & $\begin{array}{l}\text { More than } 2000 \text { firms } \\
\text { in Spain }\end{array}$ & DEA & Income & $\begin{array}{l}\text { Fixed asset Selling } \\
\text { expenses; } \\
\text { Number of } \\
\text { employees; } \\
\text { Amortization expense } \\
\text { labor costs; Operating } \\
\text { costs } \\
\end{array}$ \\
\hline Yusof et al, 2010 & $\begin{array}{l}\text { Data for the period } \\
2004-2008\end{array}$ & DEA & Revenue & $\begin{array}{l}\text { Total cost; } \\
\text { Total asset }\end{array}$ \\
\hline $\begin{array}{l}\text { Ngo Dang Thanh, } \\
2010\end{array}$ & $\begin{array}{l}22 \text { commercial banks } \\
\text { in Vietnam in } 2008\end{array}$ & DEA (VRS) & $\begin{array}{l}\text { Total asset; } \\
\text { Interest earned } \\
\text { on similar } \\
\text { investments; } \\
\text { Other income }\end{array}$ & $\begin{array}{l}\text { Salary; } \\
\text { Other costs }\end{array}$ \\
\hline $\begin{array}{l}\text { Concetta } \\
\text { Castiglione, } 2012\end{array}$ & $\begin{array}{l}\text { 3,452 manufacturing } \\
\text { companies in Italy }\end{array}$ & SFA & Net revenue & $\begin{array}{l}\text { Capital; } \\
\text { Profit on a scale; } \\
\text { Labor; } \\
\text { Materials }\end{array}$ \\
\hline Yu et al., 2014 & $\begin{array}{l}\text { Data of } 29 \text { public } \\
\text { companies in Taiwan } \\
\text { for the period 2006- } \\
2010\end{array}$ & DEA & $\begin{array}{l}\text { Revenues; } \\
\text { Other income }\end{array}$ & $\begin{array}{l}\text { Total fixed asset; } \\
\text { Number of } \\
\text { employees; } \\
\text { Operating cost }\end{array}$ \\
\hline $\begin{array}{l}\text { Huynh The } \\
\text { Nguyen, } 2019\end{array}$ & $\begin{array}{l}\text { 8,751 firm for the } \\
\text { period 2013-2016 }\end{array}$ & SFA & Net revenues & $\begin{array}{l}\text { Total fixed asset; } \\
\text { Number of } \\
\text { employees; } \\
\text { Cost of raw material }\end{array}$ \\
\hline
\end{tabular}

Source: Synthesized from previous studies 
From the above studies, with available data, we selected input and output variables to use in this study, as shown in Table 2.

Table 2: Input and output variables used to measure technical efficiency

\begin{tabular}{|c|l|l|l|l|l|}
\hline \multicolumn{5}{|c|}{ Output variable } \\
\hline No. & Variable name & Notation & Description of measurement & $\begin{array}{l}\text { Unit } \\
\text { measurement }\end{array}$ \\
\hline 1 & Net Sales & NetSales & $\begin{array}{l}\text { Gross sales less deductions for } \\
\text { sales at the end of year } t\end{array}$ & Billion dongs \\
\hline \multicolumn{5}{|c|}{ Input variables } \\
\hline 1 & $\begin{array}{l}\text { Variable name } \\
\text { firms }\end{array}$ & Notation & Description of measurement & $\begin{array}{l}\text { Unit of } \\
\text { measurement }\end{array}$ \\
\hline 2 & $\begin{array}{l}\text { Number of } \\
\text { employees }\end{array}$ & Capital & $\begin{array}{l}\text { Total equity + Liability at the } \\
\text { end of year } t\end{array}$ & Billion dongs \\
\hline 3 & $\begin{array}{l}\text { Fixed assets and } \\
\text { long-term } \\
\text { investment }\end{array}$ & Tabor & $\begin{array}{l}\text { Total number of employees in } \\
\text { the firm at the end of year t }\end{array}$ & Person \\
\hline
\end{tabular}

Source: Author's compilation

We choose Net sales as the output variable, which is used by many authors such as Concetta Castiglione (2012), Yu et al. (2014), Huynh The Nguyen (2019).

In terms of input variables, we used the main variables contributing to the production and business, such as labor, capital, and asset. The above input variables have also been selected by many authors to perform the analysis of technical efficiency of firms, such as Huynh The Nguyen (2019); Yu et al. (2014); and JoséFernández et al. (2009).

Model to evaluate the factors affecting the technical efficiency of enterprises

Table 1: Summary of factors affecting the performance of firm from previous studies

\begin{tabular}{|l|l|l|}
\hline \multicolumn{1}{|c|}{ Author } & \multicolumn{1}{|c|}{ Data } & \multicolumn{1}{c|}{ Impact variable } \\
\hline Paganetto, 2003 & $\begin{array}{l}4,000 \text { companies in } \\
\text { Italy }\end{array}$ & $\begin{array}{l}\text { Industry, size of business, age of business; } \\
\text { companies in export group; tax incentives. } \\
\text { Debt ratio; earnings before tax; interest rate; } \\
\text { dummy variable on successful investment in } \\
\text { new products and process; ICT }\end{array}$ \\
\hline Vania Sena, 2004 & $\begin{array}{l}\text { Manufacturing } \\
\text { companies }\end{array}$ & Debt ratio; total equity to total asset ratio \\
\hline Her-Jiun Sheua et al, 2005 & $\begin{array}{l}\text { Electronics } \\
\text { companies in } \\
\text { Taiwan }\end{array}$ & $\begin{array}{l}\text { Company size; age; ownership ratio of the } \\
\text { parent company; ownership ratio of majority } \\
\text { shareholders and board of directors }\end{array}$ \\
\hline
\end{tabular}


Table 3: Continued

\begin{tabular}{|l|l|l|}
\hline Prabowo et al., 2011 & $\begin{array}{l}\text { 121 listed } \\
\text { companies in } \\
\text { Indonesia }\end{array}$ & Company age; size; market share; industry \\
\hline Concetta Castiglione, 2012 & $\begin{array}{l}3,452 \\
\text { manufacturing } \\
\text { companies in Italy }\end{array}$ & $\begin{array}{l}\text { ICT; company size; type; geographical } \\
\text { location; fields of operation }\end{array}$ \\
\hline Santarelli and Hien Tran, 2013 & $\begin{array}{l}\text { Manufacturing } \\
\text { companies }\end{array}$ & $\begin{array}{l}\text { Single-segment firms and multi-segment } \\
\text { firms; and method of using indicators of } \\
\text { diversification such as Entropy index }\end{array}$ \\
\hline Huynh The Nguyen, 2021 & $\begin{array}{l}\text { 8,751 companies in } \\
\text { the period of 2013- } \\
\text { 2016 }\end{array}$ & $\begin{array}{l}\text { Age; size; productivity; export; government } \\
\text { support; foreign ownership; capital structure }\end{array}$ \\
\hline $\begin{array}{l}\text { Long Hau LE and Tan Nghiem } \\
\text { LE, 2020 }\end{array}$ & $\begin{array}{l}\text { Households in the } \\
\text { Mekong river delta }\end{array}$ & Diversification improves income \\
\hline
\end{tabular}

Source: Author's compilation

According to the above studies as well as the collected data, we used the dependent and

independent variables for the GMM model as follows :

$\mathrm{TE}_{\mathrm{it}}=\mathrm{a}_{0}+\mathrm{a}_{1}{ }^{*} \operatorname{LnTA}_{\mathrm{it}}+\mathrm{a}_{2}{ }^{*}$ LnSales $_{\mathrm{it}}+\mathrm{a}_{3}{ }^{*}$ Invest $_{\mathrm{it}}+\mathrm{a}_{4}{ }^{*}$ DebtRatio $_{\mathrm{it}}+\mathrm{a}_{5}{ }^{*}$ DebtRatio $_{\mathrm{it}}{ }^{2}+\mathrm{a}_{6}{ }^{*} \mathrm{ETA}_{\mathrm{it}}+\mathrm{a}_{7}{ }^{*} \mathrm{LP}_{\mathrm{it}}+$ $\mathrm{a}_{8}{ }^{*}$ ICTindex $_{\mathrm{it}}+\mathrm{a}_{9}{ }^{*}$ Entropy $_{\mathrm{it}}+\mathrm{e}_{\mathrm{it}}$

In which :

The independent and dependent variables are described in detail in Table 4

$\mathrm{a}_{0}$ is the intercept

$\mathrm{e}_{\mathrm{it}}$ is the standard error

$a_{1}, a_{2}, \ldots a_{9}$ are the marginal effect coefficients

Table 2: Variables and factors affecting the technical efficiency of Vietnamese enterprises

\begin{tabular}{|c|c|c|c|c|}
\hline \multicolumn{5}{|c|}{ Dependent variable } \\
\hline No. & Variable name & Notation & Measurement & $\begin{array}{c}\text { Unit of } \\
\text { measurement }\end{array}$ \\
\hline 1 & $\begin{array}{l}\text { Technical } \\
\text { efficiency }\end{array}$ & $\mathrm{TE}$ & Result from DEA method & $\begin{array}{l}\text { Actual value } \\
\text { from } 0-1\end{array}$ \\
\hline \multicolumn{5}{|c|}{ Independent variables } \\
\hline No. & Variable name & Notation & Measurement & $\begin{array}{c}\text { Unit of } \\
\text { measurement }\end{array}$ \\
\hline 1 & Asset size & $\operatorname{lnTA}$ & Ln (Total asset) & times \\
\hline 2 & Market size & InSales & Ln (Net sales) & times \\
\hline 3 & $\begin{array}{l}\text { Investment } \\
\text { ratio }\end{array}$ & Invest & $\begin{array}{l}\text { Fixed asset \& Long-term investment / Total } \\
\text { asset }\end{array}$ & $\%$ \\
\hline
\end{tabular}


Table 4: Continued

\begin{tabular}{|c|l|l|c|l|}
\hline 4 & Debt ratio & DebtRatio & $\frac{\text { Average total debt }}{\text { Average total equity }}$ & $\%$ \\
\hline 5 & $\begin{array}{l}\text { Square of Debt } \\
\text { ratio }\end{array}$ & DebtRatio $^{2}$ & Square of Debt Ratio & - \\
\hline 6 & Equity ratio & ETA & $\frac{\text { Total equity }}{\text { Total liabilities and equity }}$ & $\%$ \\
\hline 7 & $\begin{array}{l}\text { Labor } \\
\text { productivity }\end{array}$ & LP & $\frac{\text { Net sales }}{\text { Number of employees }}$ & $\%$ \\
\hline 8 & ICT & ICT index & ICT ranking index of provinces & - \\
\hline 9 & $\begin{array}{l}\text { Diversification } \\
\text { index }\end{array}$ & Entropy & $\begin{array}{l}D T_{i t}=\sum_{i=1}^{n}\left[P_{i} \times \ln \left(\frac{1}{P_{i}}\right)\right] \quad(2) \\
P_{i} \text { is the sales ratio of segment i (segment }- \\
\text { level } 4)\end{array}$ & $\begin{array}{l}\text { Value from } 0- \\
1\end{array}$ \\
\hline
\end{tabular}

Source: Author's compilation

\section{Research hypothesis}

The research aims and questions are all about examining the impact of two key factors, the ICT index and the business diversification index of enterprises from 63 different provinces and cities in Vietnam. (through equations (1) and (2) above). From that point of view, along with the literature review on previous studies, we propose two research hypotheses as follows:

- Hypothesis H1:The ICT index has a positive effect on the technical efficiency of enterprises in different provinces, and the ICT index is an important index to help improve the efficiency of firms.

Nowadays, almost all businesses, from large enterprises to small and medium enterprises, use computers, the internet, specialized software, and information technology applications in the process of product management and selling goods and services. Many studies also agree that ICT is an important indicator and businesses that focus on it will save costs and increase efficiency. Concetta Castiglione (2012) and Bedoya and Paganetto (2003) also included this variable to consider its positive effect.

- Hypothesis H2: Enterprises in provinces with a high business diversification index help reduce risk and enhance business efficiency.

Indeed, there is currently much research exploring business diversification in many countries, in which diversification is categorized by different levels of business diversification such as product, industry, or market, with results of a positive effect on business performance. Studies supporting this result come from multiple authors. Typically, research such as Pandya and Rao (1998), exploring data from US companies from 1981-1990, classifying companies into 3 diversification groups: undiversified enterprises, moderately diversified enterprises and highly diversified enterprises. The results indicated that the performance of diversified enterprises is better than that of nondiversified enterprises. In particular, moderately diversified enterprises have the best performance. Ade Oyedijo (2012) investigated the influence of product diversification strategy on the financial efficiency and growth of firms. Research results show that related diversification had a significant impact on financial performance, while unrelated diversification had a negative but insignificant impact on financial performance. Berg (2016) studied the impact of diversification on the performance of enterprises in India. The results proved that diversified firms have a higher level of efficiency than non-diversified firms. W.Su and Eric Tsang (2015) explored the relationship between product diversification and financial efficiency and the role of the third party (in this study, it includes religious organizations and non-profit organizations); their research showed that related third parties have a positive regulatory role in the relationship between product diversification and efficiency. 


\section{DISCUSSION}

\section{Descriptive statistics}

Table 5. Descriptive statistics

\begin{tabular}{|l|l|l|l|l|l|}
\hline & \multicolumn{1}{|c|}{ Unit } & \multicolumn{1}{c|}{ Minimum } & \multicolumn{1}{c|}{ Maximum } & \multicolumn{1}{c|}{ Mean } & \multicolumn{1}{c|}{ Std.dev } \\
\hline Net sales & Bil VND & $4,021.00$ & $5,399,432.00$ & $277,962.90$ & $694,871.57$ \\
\hline Capital & Bil VND & $7,584.00$ & $8,988,171.00$ & $364,888.31$ & $1,179,056.19$ \\
\hline Employees & person & $7,156.00$ & $2,958,127.00$ & $212,794.14$ & $463,243.10$ \\
\hline FA \& LT investment & Bil VND & $2,328.00$ & $3,820,547.00$ & $151,990.38$ & $461,681.33$ \\
\hline Total assets & Bil VND & $16,815.96$ & $30,199,062.02$ & $1,054,845.62$ & $3,571,012.37$ \\
\hline Investment ratio & $\%$ & 2.59 & 36.02 & 16.93 & 4.86 \\
\hline Debt ratio & $\%$ & 0.80 & 8.60 & 1.78 & 0.80 \\
\hline Equity ratio & $\%$ & 10.30 & 57.90 & 37.86 & 7.61 \\
\hline Labor productivity & $\%$ & 0.26 & 3.85 & 1.15 & 0.63 \\
\hline ICTindex & $0-1$ & 0.091300 & 0.940700 & 0.421972 & 0.137031 \\
\hline Deverindex & $0-1$ & 0.000167 & 0.184921 & 0.011498 & 0.028238 \\
\hline
\end{tabular}

Source: Author's calculation

Table 5 describes the statistical values of variables in the models. The observed data comprises 63 provinces in the period from 2015 to 2018 ( 4 years), so the total number of sample in the study is $63^{*} 4=252$ observations which meet the reliability requirement.

The descriptive statistics of variables in Table 4.3 show that the values of sales, capital, total assets have high volatility; the difference between the maximum and minimum value is quite high and likely to be heteroskedasticiy. The average investment ratio of enterprises is $16.93 \%$, the average debt ratio of enterprises is quite low, only $1.78 \%$, the largest ratio is only $8.6 \%$, and the equity ratio is also low at only $37.86 \%$ on average. The average labor productivity also reaches 1.15 times, the ICT and diversification index are also at a low level.

\section{Results of technical efficiency}

Results of technical efficiency (TE) indicate that, although the input variables are the same in provinces, the various input and output values in each province have made differences in efficiency (maximize inputs). These results show significant gaps in technical efficiency among a number of provinces (some with TE of 1 (100\%) while others with TE of under 0.4 (40\%). The detailed findings are shown in Figure 1

Technical efficiency has fluctuated over the years. Based on the series of analytical results, it can be categorized into four groups: a group of enterprises in provinces with sustainable technical efficiency, a group of enterprises in provinces with unsustainable technical efficiency, a group of enterprises in provinces with improvement in technical efficiency, and a group of enterprises in provinces with decrease in technical efficiency. The group of enterprises in the provinces with sustainable efficiency accounts for $9.52 \%$, typically HCMC, with TE at $100 \%$ over many years. The group of enterprises in provinces with unsustainable efficiency accounts for $4.76 \%$. Bac Lieu and Soc Trang are two of them, achieving efficiency in 2015 and 2016, but then the overuse and misuse of inputs increases, leading to the dropping of efficiency. The group of enterprises in provinces with improved efficiency accounts for $47.6 \%$, in particular, Can Tho with TE reaching $60.6 \%$ in year 2015, but rising to $66.5 \%$ in year 2018 . 
Finally, the group of enterprises in provinces with a reduction in efficiency, which have not maximized their resources. Hanoi is an example
(TE went down from $94.8 \%$ in 2015 to $83.6 \%$ in 2018).

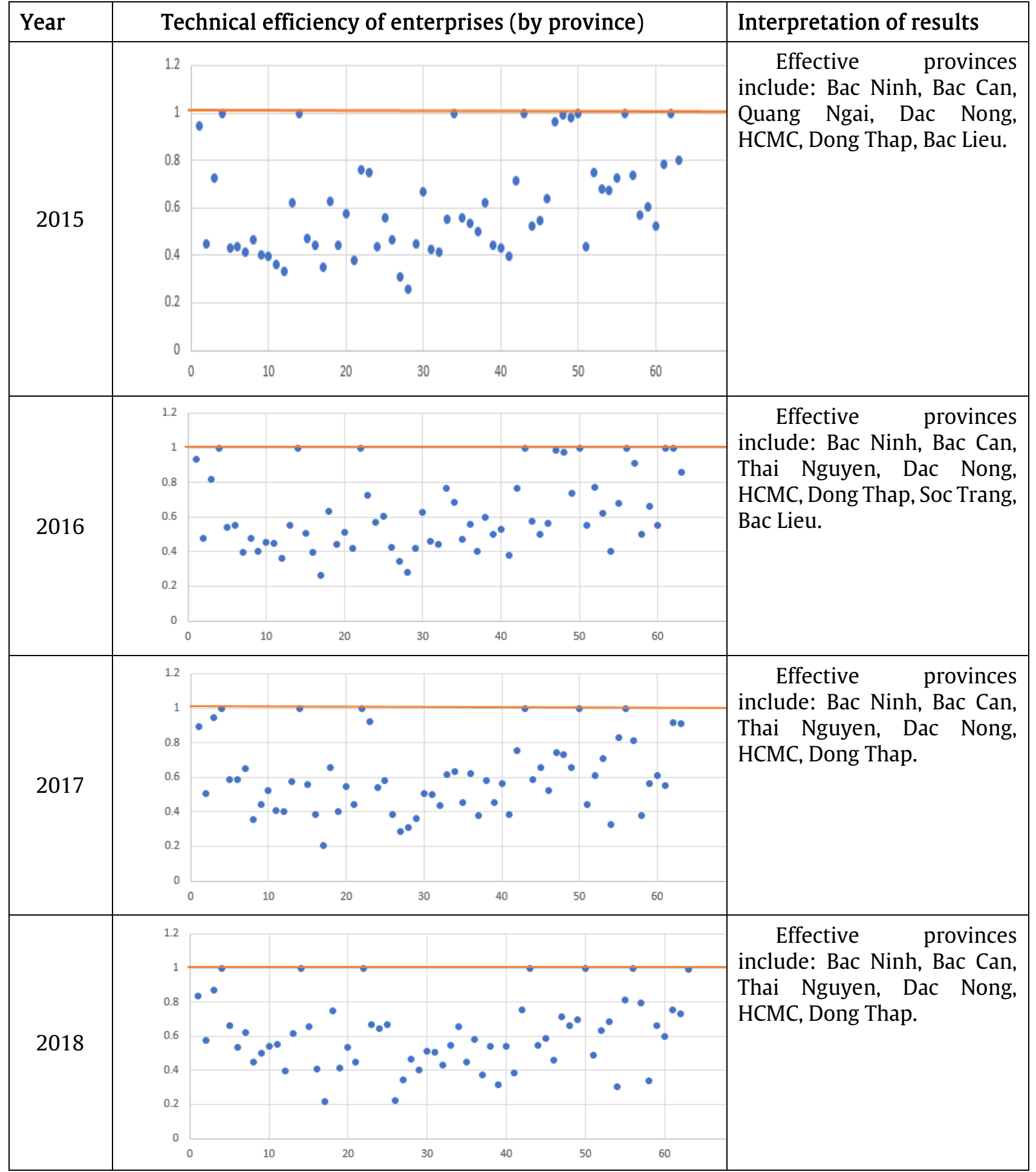

Figure 1: Results of technical efficiency

Source: Author's calculation 
The above results indicate that even some of the leading economic provinces like Hanoi or Dac Nang, Can Tho has not yet achieved technical efficiency, because sometimes the investment is spreading, policies to attract investment for businesses and the ability of management are still inadequate or limited, leading to not achieving the desired effect. Enterprises in effective provinces show that the ICT index and also the level of business diversification of enterprises are stable or improved.

\section{Results of analyzing factors affecting technical efficiency}

In the GMM method, the finding of endogenous variables and the number of instrumental variables are very important. Gujarati (2011) suggests that in case the model has 1 endogenous variable, the empirical rule is that in the Hausman test, if the statistical value $F>10$, the selected instrumental variable is not weak and acceptable. According to Hill, Griffiths, and Lim (2012), the instrumental variable is not correlated with the standard error, that is
$\operatorname{Cov}(\mathrm{Z}, \mathrm{u})=0$, if this condition is false, then the IV estimation will be not consistent.

Turning back to the results of Weil (1990), focusing on the use of ICT and concluding that the productivity enhancement belongs to the context, it was found that ICT applications during data processing contribute to productivity enhancement while strategic systems such as sales support do not contribute at all to productivity. (Brynjolfsson 1993) stated that the early impact and goal of ICT is to increase product diversification. Omar A. León et al. (2016) claimed that advances in ICT have paved the way for new types of opportunities for companies to broaden their horizon to explore new markets and diversify businesses. With the above arguments, in this study, we suspect that ICT is an endogenous variable.

The empirical results show that the ICT variable is endogeneous, and three instrumental variables (IV) which are optimally selected include ROA, ROE and market share. The detailed results are shown in the following table 6

Table 6. Regression results of factors affecting technical efficiency by GMM method

\begin{tabular}{|l|c|l|}
\hline Impact variable TE & $\begin{array}{c}\text { Marginal impact } \\
\text { coefficient }\end{array}$ & P-value \\
\hline ICT index & 0.6887 & 0.200 \\
\hline LnTA & -0.1296 & $0.008\left(^{*}\right)$ \\
\hline Invest & 0.0190 & $0.000\left(^{*}\right)$ \\
\hline Debt-ratio & 0.1386 & 0.184 \\
\hline Debt-ratio ${ }^{2}$ & -0.0087 & 0.269 \\
\hline E/TA & 0.0057 & 0.279 \\
\hline Entropy & 5.6035 & $0.000\left(^{*}\right)$ \\
\hline LP & 0.1673 & $0.000\left(^{*}\right)$ \\
\hline Const & 1.0832 & $0.012\left(^{* *}\right)$ \\
\hline R-Square & 0.5906 & \\
\hline
\end{tabular}

Source: calculation result from Stata

Note: an asterisk $\left({ }^{*}\right)$ and $\left({ }^{* *}\right)$ represents the significant level of $1 \%$ and $5 \%$, respectively

Table 6 shows the results of factors affecting the technical efficiency of firms. The above results indicate that the ICT index and the degree of diversification both have a positive effect on efficiency, proving hypothesis $\mathrm{H} 1$, consistent with the research results of Concetta Castiglione 
(2012) and Bedoya and Paganetto (2003). The diversification index especially has the highest marginal impact coefficient and is in the same direction as the technical efficiency of firms. The results also support hypothesis $\mathrm{H} 2$, relevant to the research results of Pandya and Rao (1998); Ade Oyedijo (2012; and Berg (2016), showing that existing enterprises that want to improve efficiency need to focus on product diversification and business lines. In comparison with the results of the above qualitative analysis, the current enterprises have a very low level of diversification, which is a limitation in product development, market expansion and efficiency improvement.

The size of total assets has a negative impact on efficiency. This result implies that enterprises need to be cautious in increasing the size of total assets, especially enterprises in provinces that have not yet achieved an efficient level, have poorly used assets, have not exploited the full potential, and with low assets performance. The debt ratio has a positive effect, while the square of this variable has a negative effect. This result indicates that there is an inverse U-shaped nonlinear relationship between the debt ratio and efficiency (in the early stage, increasing debt helps improve efficiency, yet increasing debt beyond an acceptable threshold reduces efficiency). Equity has a positive relationship with efficiency, indicating that increasing the equity ratio and reducing debt are combined factors in reducing risk and improving efficiency. Finally, the labor productivity variable also has a positive impact on efficiency; apparently labor productivity is an important factor so managers need to pay attention to enhancing labor efficiency and productivity, avoiding wastefully using human resources in the wrong place and wrong time.

\section{CONCLUSION AND RECOMMENDATION}

From the results of the efficiency analysis using the DEA method, we find that there are four different groups after classifying enterprises in different provinces, including: a group with stable technical efficiency such as enterprices located in HCMC, BacNinh and BacCan , a group with decrease in efficiency (such as enterprices located in HaNoi, QuangNam and BaRiaVT), a group with increase in efficiency (such as enterprices located in HaiPhong, Hue, CanTho), and a group with unstable efficiency (such as enterprices located in QuangNgai, KhanhHoa, SocTrang). Based on this analysis, both government agencies and company managers need to pay attention to reviewing and reevaluating their actual current condition and have appropriate solutions and policies to remain stability and improve the technical efficiency.

From the above research results, the author makes some recommendations and implications as follows:

Solutions to raise the ICT index for provinces: The Vietnam ICT Index is structured according to the United Nations' index system, consisting of three main component indexes: Technical infrastructure, Human infrastructure, and IT Application. Therefore, in order to boost the ICT index, provinces need to: (1) Prioritize allocation of funds to invest in the technical infrastructure of government agencies; (2) Pay attention to investment in human resource development of government agencies at all levels; and (3) Thoroughly apply IT in government agencies

Solutions to increase the level of business diversification: Enterprises should conduct business in many different sectors or operate in many areas at the national level. This will benefit them. However, each enterprise needs to consider the following: business characteristics, specific industry and financial capacity to decide whether to undertake industry diversification or national diversification, as well as the extent of these types of diversification.

Solutions to improve labor productivity at enterprises: We have some recommendations to improve labor productivity at the enterprise level, as follows. (1) It is necessary for enterprises to increase investment in employee education and training regarding new production technologies, as labor productivity is directly proportional to society's capital on labor. (2) Identification of the appropriate production model and following market drivers should be kept in mind consistently. (3) Three production stages - product designing, product consumption and branding - should be synchronized. (4) The banking regulatory body should implement measures to keep the credit market strong and 
accessible for various types of enterprises to serve the needs of capital. (5) Firms should pay attention to both domestic and oversea markets, and particularly stimulate domestic consumption demand. (6) ) There should be an adequate investment budget for research and development activities at both the enterprise and state levels. (7) Government authorities need to improve their effectiveness of state management, and the public administrative services should be more transparent and convenient.

Although this research has important contributions, including (1) showing which province having enterprises that are effective and which province having enterprises that are ineffective for improvement, and (2) proving the role of ICT and business diversification on corporate performance, it still has limitations such as the statistical indicators are the average of the whole province, and there is no data for each enterprise in each province. Another limitation is that the ICT index is also calculated at the provincial level with the assumption that the province's ICT has an indirect influence on the enterprise performance; there is yet no separate ICT data for each enterprise.

\section{ACKNOWLEDGEMENT}

This research is funded by Vietnam National University Ho Chi Minh City (VNU-HCM) under grant number B2020-34-02/HĐ-KHCN

\section{REFERENCES}

Ade, Oyedijo (2012). Antecedents and

Performance Outcomes of Strategic Planning in Nigerian Public Universities.

International Journal of Asian Social Science, Asian Economic and Social Society, vol. 2(4), pages 448-461, April.

Alberto, Bayo Moriones; Margarita, Billon \& Fernando, Lera-Lopez (2011). Perceived performance effects of ICT in manufacturing SMEs. Industrial Management \& Data Systems 113(1)

Bedoya \& Paganetto (2003). ICT Investment, Productivity and Efficiency: Evidence at Firm Level Using a Stochastic Frontier Approach. Journal of Productivity Analysis, Vol. 20, issue 2, 143-167
Berger \& Ofeck (1995). Diversification's effect on firm value. Journal of Financial Economics, Vol. 37, Issue 1, January 1995, Pages 39-65

Brynjolfsson and Hitt (1993). Beyond the IT Productivity Paradox. Communications of the ACM 41(8):49-55

Concetta, Castiglione (2012). The consumption of cultural goods through the internet. How is it affected by the digital divide? ACEI Working Paper Series AWP-04-2016

Dang, Thi Viet Duc (2019). Impact of information and communication technology on Vietnam's economy. Financial Reviews, Mar 2019

David, Mhlanga (2021). Artificial Intelligence in the Industry 4.0 and Its Impact on Poverty, Innovation, Infrastructure Development, and the Sustainable Development Goals: Lessons from Emerging Economies? Sustainability, May 2021

Dolores, Añón Higón (2011). The impact of ICT on innovation activities: Evidence for UK SMEs. International Small Business Journal 30 (6):684-699

Eden (2018). From Computer Ethics to Responsible Research and Innovation in ICT: The transition of reference discourses. Information \& Management, 51(6). https:doi:10.1016/j.im.2014.01.001

Enrico, Santarelli and Hien Tran (2013). The interplay of human and social capital in shaping entrepreneurial performance: the case of Vietnam. Small Business Economics, 2013, Vol. 40, issue 2, 435-458

Her, Jiun Sheu et al (2005). Insider ownership and firm performance in Taiwan's electronics industry: a technical efficiency perspective. Managerial and Decision Economics, Vol 26, issue 5, 307-318. https://doi.org/10.1002/mde.1228

Long Hau LE and Tan Nghiem LE (2020). Income Diversification Among Rural Households in the Mekong River Delta, Vietnam: A Look Back at the Economic Transition Period. Research in World Economy, Vol 11, No.3. https://doi.org/10.5430/rwe.v11n3p124

Huynh, The Nguyen (2021). Factors affecting technical efficiency in small and medium enterprises in Vietnam. Journal of the Asia 
Pacific Economy, March 2021. https://doi.org/10.1080/13547860.2021.190 2600

Jose'Fernández-Menéndez et al (2009). Prevalence, Diagnosis, Treatment, and Control of Hypertension in Spain. Rev Esp Cardiol. 2016 ; 69(6):572-578

Khuong (2019). https://www.vnu.edu.vn/ttsk/?C1654/N251 24/PGS.TS.-Vu-Minh-Khuong

León at al (2016). Relationship between the use of ICT and the degree and type of diversification. Conference on ENTERprise Information Systems / International Conference on Project MANagement / Conference on Health and Social Care Information Systems and Technologies, CENTERIS / ProjMAN / HCist 2016, October 5-7, 2016

Loveman, G. W. (1998). Employee Satisfaction, Customer Loyalty, and Financial Performance: An Empirical Examination of the Service Profit Chain in Retail Banking. Journal of Service Research, 1(1), 18-31

Manal, Yunis (2018). The role of ICT and innovation in enhancing organizational performance: The catalysing effect of corporate entrepreneurship. Journal of Business Research, 2018, vol. 88, issue C, 344-356

Ngo, Dang Thanh (2010). Measuring the performance of the banking system: case of Vietnam (1990-2010). Journal of applied finance and banking, 2012

Nguyen, Viet Hung (2008). Factors affecting the performance of Vietnamese commercial banks. PhD thesis 2008

Paganetto et al (2003). ICT Investment, Productivity and Efficiency: Evidence at Firm Level Using a Stochastic Frontier Approach. Journal of Productivity Analysis, Vol 20, pages143-167 (2003)

Pandya and Rao (1998). Diversification and firm performance: An empirical evaluation. Journal of Financial and Strategic Decisions, Vol 11, No. 2, 67-81

P.G Berger and E.Ofek (1995). Diversification's effect on firm value. Journal of Financial Economics 37 (1995) 39-65
Phillip, Koellinger (2006). Impact of ICT on Corporate Performance, Productivity and Employment Dynamics. e-Business W@tch, European Commission, DG Enterprise \& Industry, Special Report No. 01/2006

Prabowo et al (2011). Independent directors and firm performance in family-controlled firms: evidence from Indonesia. Asian Pacific Economics Literature, 9 May 2011. https://doi.org/10.1111/j.14678411.2011.01276.x

Rafi Ashrafi and Muhammed Murtaza (2008). Use and Impact of ICT on SMEs in Oman. The Electronic Journal Information Systems Evaluation, Vol 11, Issue 3 2008, pp. 125 138

Roberto, Alvarez et al (2016). The Impact of R\&D and ICT Investment on Innovation and Productivity in Chilean Firms. American Development Bank. Competitiveness and Innovation Division, Jun 2016

Roghieh, Gholami et al (2003). The Causal Relationship between ICT and FDI, Electronic. Conference: Proceedings of the 11th European Conference on Information Systems, ECIS 2003, Naples, Italy 16-21 June 2003

Samwel et al (2020). Challenges facing women in ICT from a women perspective: A case study of the Zimbabwean Banking Sector and Telecommunications Industry. Journal of Systems Integration 2020/1. DOI:10.20470/jsi.v11i1.389

Samwel Macharia Chege at el (2020). Impact of information technology innovation on firm performance in Kenya. Information Technology for Development, Volume 26, 2020

Shen H., Dong Wang and Zhongfeng Su. Diversification and firm performance in China. African Journal of Business Management 5 (2011) 99-104

Stephen Tallman and Jiatao Li (1996). Effects of International Diversity and Product Diversity on the Performance of Multinational Firms. The Academy of Management Journal 39(1):179-196

Vania Sena (2004). The Return of the Prince of Denmark: A Survey on Recent 
Developments in the Economics of Innovation. Economic Journal, 2004, vol. 114

Yusof et al (2006). Measuring Efficiency of Insurance and Takaful Companies in Malaysia Using Data Envelopment Analysis (DEA). Review of Islamic Economics, Vol.10, No.2, pp 5-26

You et al (2020), Energy Efficiency Evaluation Based on Data Envelopment Analysis: A Literature Review. Energies journal 2020, Vol 13, Issue 14.

https://doi.org/10.3390/en13143548

\section{ABOUT THE AUTHORS}

Anh Phong Nguyen, mail: phongna@uel.edu.vn

Dr. Anh Phong Nguyen is an Associate Professor and Dean of Faculty of Finance and Banking, University of Economics and Law at the Vietnam National University, Ho Chi Minh City, Vietnam.

Thi Hong Minh Ho is the Lecturer in the Faculty of Finance and Banking, at the University of Economics and Law, Ho Chi Minh City, Vietnam; Vietnam National University, Ho Chi Minh City, Vietnam.

Thi Thanh Truc To is the Lecturer Faculty of Finance and Banking, in the University of Economics and Law, Ho Chi Minh City, Vietnam; Vietnam National University, Ho Chi Minh City, Vietnam

Anh Vu Nguyen is a Faculty of Finance and Banking, at the University of Economics and Law, Ho Chi Minh City, Vietnam; Vietnam National University, Ho Chi Minh City, Vietnam. 